YAK 342.7

ББК 67.400 .3

DOI 10.22394/1682-2358-2021-6-84-91

S.A. Rabazanov, postgraduate student of the Constitutional and International Law Department, Povolzbsky Institute of Management named after P.A. Stolypin, Branch of the Russian Presidential Academy of National Economy and Public Administration

\section{PECULIARITIES \\ OF REALIZATION \\ OF RIGHTS \\ AND FREEDOMS \\ BY COLLECTIVE \\ ENTITIES \\ IN THE CONTEXT OF DIGITALIZATION}

The process of introducing digital technologies into the everyday life of social communities is considered and the changes taking place, both positive and negative in nature, are highlighted. The need for participation of both the state and society in this process for its final completion is noted. Ways and methods of solving the problematic issues that arise in this course are analyzed.

Key words and word-combinations: Constitution of the Russian Federation, social communities, digitalization, small indigenous peoples.
С.А. Рабазанов, аспирант кафедри конституиионного и международного права ПоВолжского института упраһления имени П.А. Стольтпна - филиала Российской академии народного хозяйства и государственной службь при Президенте РФ (email: rabazanov2420@gmail.com)

\section{ОСОБЕННОСТИ РЕААИЗАЦИИ ПРАВ И СВОБОА КО $\Lambda$ ЕКТИВНЫМИ СУБЪЕКТАМИ В УСАОВИЯХ ЦИФРОВИЗАЦИИ}

Аннотация. Рассматривается процесс внедрения цифровых технологий в повседневный быт социальных общностей как коллективных субъектов конституционных отношений. Отмечается необходимость участия как государства, так и общества в данном процессе для его окончательного завершения. Анализируются пути и способы решения возникающих при этом проблемных вопросов.

Ключевые слова и словосочетания: Конституция РФ, социальные общности, цифровизация, коренные малочисленные народы.<smiles>[IH-]</smiles>
редставить современный мир без цифровых технологий уже невозможно. Процесс цифровизаџии охватил все сферы общественной жизни и глубоко вошел в повсеАневный быт мюдей. ОАнако, как и мюбое Аругое явление, цифровизация не может быть внеАрена во все сферы с одинаковым успехом. Нет смысла сравнивать уровень освое- 
ния цифровых технологий странами Африки и Европы. Очевидно, что Аанный проџесс в этих странах находится на несопоставимом уровне. Важно исследовать степень доступности современных цифровых технологий и сопутствующих с ними новых возможнностей в Российской Федерации Амя социальных общностей как комективных субъектов конституџионных отношений [1, с. 208], а также попытаемся прослеАить происходящие изменения в их деятельности.

Е.Г. Зборовский полагает, что соџиальная общность - это один из основных типов соџиальной системы, выступающей в качестве реально существующей, эмпирически фиксируемой, относительно еАиной и самостоятельной совокупности (взаимосвязи) мюдей, объединенных по социокультурным, демографическим, экономическим, этническим, территориальным, религиозным, политическим, профессиональным и иным основаниям [2, с. 9]. В Аанной публикации сосредоточим внимание на социальных общностях, которые объединены по этническим основаниям, - коренных малочисленных народах.

В российской правовой доктрине отношение к коренным малочисменным народам общества носит особый характер, так как Российская Федерация - это многонациональная страна [3], где в тесном взаимодействии многие годы сосуществуют множество представителей социальных групп. Необходимость более качественной и целевой деятельности со стороны государства и общества в заданном направлении во многом связана с определенной уязвимостью и незащищенностью Аанных соџиальных субъектов в рамках всего общества, поэтому государство пытается уделить им больше внимания с целью улучшения соџиально-экономического положения. В связи с этим наряАу с нормативными правовыми актами общего значения, которые регулируют общественные отношения в целом, по поводу рассматриваемых социальных общностей действуют правовые акты адресного характера. Таким законом является Федеральный закон от 30 апреля 1999 г. № 82-Ф3 «О гарантиях прав коренных малочисленных народов Российской Федерации», который устанавливает правовые основы гарантий самобытного соџиально-экономического и культурного развития коренных малочисменных народов Российской Федерации, защиты их исконной среды обитания, традиџионных образа жизни, хозяйственной деятельности и промыслов.

Процесс цифровизации малых народов - комлективных субъектов конституционного права - характеризуется уровнем доступности информационно-коммуникационных технологий в среде их обитания, что нелегко достигается в России - стране с огромной территорией, где удаленность населенных пунктов нередко весьма велика от «цен- 
тра». По мнению И.И. Брянцева, внедрение цифровых технологий в среду обитания коренных малочисленных народов меняет формат их повседневной жкизни, создает новые формы общественных отношений и, как следствие, приводит к повышению эффективности экономики и укучшению качества жизни [4, с. 58] .

Отметим, что государство и общество активно работают в данном направлении. Проект «Цифровизация языкового и культурного наслеАия коренных народов Арктики» [5], предназначенный Амя сохранения и развития языкового и культурного многообразия коренных народов Арктики на цифровых носителях и представления их в мировом информационном пространстве, начал свое развитие в 2011 г. и продолжается в настоящее время. В Интернете предполагается создать единую поликультурную среду народов, проживающих в Арктике, что позволит сохранять, развивать и популяризировать языки и культуру, а также расширить среду общения на родных языках и обеспечить цифровую идентичность кажАого коренного народа.

Цемевые государственные программы направлены на поддержание слабозащищенной части российского общества в связи с необходимостью решения существующих в их жкизни проблем.

Во-первых, вопросы зАравоохранения. В большинстве своем коренные народы, особенно проживающие в отдаленных районах с плохими климатическими условиями, мишены квалифицированной медицинской помощи и вынужжены прибегать к традиционной медицине. В подобных ситуациях современные цифровые технологии посредством использования возможностей телемедиџины могут быть весьма полезны. Телемедицина как часть традиционной медицины дает возможность использовать цифровые технологии для решения отдельных кАинических вопросов [6]. Специалисты более высокой квацификации в режиме реального времени могут проконсультировать, Аать указания по жизненно важным вопросам, проконтролировать определенный клинический проџесс, что крайне важно для местных работников зАравоохранения.

Статья 36.2 Федерального закона от 21 ноября 2011 г. № 323-Ф3 «Об основах охраны здоровья гражжан Российской Федерации» регламентирует порядок оказания медицинской помощи с использованием телемедиџинских технологий [7]. Аанная норма была принята мишь в 2017 г., что, на наш взгляА, явцяется, хотя несколько запоздалым, но весьма важным решением государства - события последнего времени, связанные с распространением коронавирусной инфекции, это поАтверАили.

Во-вторых, Аистанционное получение государственных ускуг. Учи- 
тывая, что многие коренные народы находятся в отдаленных районах, в том числе в районах Крайнего Севера, получение государственных услуг на месте прожкивания было бы целесообразно и актуально. Основной причиной реацизации такой программы явцяется не столько необходимость уравнивания в возможнностях всех граждан Российской Федерации, хотя и это имеет огромное значение, а невозможность данных социальных групп в определенное время года в связи с суровыми природно-климатическими условиями добраться до места нахождения государственного учрежАения, преАоставмяющего ту ици иную госуАарственную ускугу.

6 мая 2008 г. Правительство РФ утвердило Концепцию электронного правительства, где сформировано Ава основных этапа развития: разработка и утверждение необходимых документов до конџа 2008 г. и начало их применения на практике с 2009 по 2010 г. [8, с. 172]. В начале 2011 г. запущена программа «Информационное общество» [9] , с принятием которой в стране началось развитие системы цифрового государственного управления. В ее рамках разработан один из широко известных эмектронных ресурсов по предоставлению государственных ускуг - «Единый портал государственных и муниципальных услуг». Указанная программа продолжала свое развитие до 2020 г.

В-третьих, возможность получения образования дистанционно, с усвоением необходимого учебного материала без постоянного и непосреАственного контакта преподаватемей с обучаемыми. ПреАставители рассматриваемых субъектов права могут пройти курс подготовки, переподготовки ици повышения квалификации, не меняя привычного образа жизни и сохраняя свою культурную самобытность.

Традиционная форма обучения имеет ряд недостатков, которые наиболее остро ощущаются коренными народами. Во-первых, большинство крупных учебных заведений расположены в центральной части страны, преодоление этого расстояния требует значительных финансовых расходов, что непосильно многим чценам российского обшества. Вовторых, существует финансовая проблема, связанная с оплатой обучения, так как конкурс на бюджетные места достаточно высок. По мнению С.В. Ааџкова, Аистанционное образование позволяет решить указанные проблемы, ибо не требует значительных финансовых и временных затрат [10]. В начале распространения коронавирусной инфекции Министерство просвешения РФ выпустило, опубликовало и разослало по субъектам страны методические рекомендации [11] с подробным изможением порядка организаџии дистанџионного обучения.

На наш взгляА, разработка и внедрение современных цифровых технологий преАставяителями малых народов России невозможны без 
постоянной квалифицированной помощи. К решению этой проблемы, кроме органов государственной власти, могут быть привлечены и Аругие коммективные субъекты конституционного права, например общественные объединения [1, с. 205]. В настоящее время дия защиты прав и интересов коренных народов создано достаточно много общественных объединений, занимающихся разными направлениями. В силу того, что многие преАставители малых народов имеют весьма туманное представление о современных цифровых технологиях, их внеАрение может восприниматься неоднозначно, с недоверчивостью. В таких случаях чиены общественных объединений способны стать посредниками в решении вопросов цифровизации, так как имеют более тесную связь с мюАьми, а нередко сами явцяются преАставителями этих социальных общностей.

Аля вопмощения в жизнь достижений цифровизации прежде всего необходимо организовать Аоступ к сети «Интернет» в труднодоступных районах. Президент РФ 3 февраля 2014 г. поставил задачу по устранению цифрового неравенства в Российской Федерации [12], которая не решена до сих пор. Сегодня эта программа находится на этапе завершения, около 17 тыс. населенных пунктов с численностью от 250 до 500 человек получили доступ к Интернету, а 25 тыс. насеменных пунктов численностью от 100 до 250 человек не имеют такой возможности [13]. В апреле 2020 г. В.В. Путин подписал поправки в Федеральный закон «О связи», которые оптимизируют оказание ускуг связи в населенных пунктах численностью от 100 человек [14]. К концу июня 2024 г. планируется окончательно решить данный вопрос и обеспечить практически каждому жителю страны доступ в мир цифровых технологий.

Программа цифровизации реализуется с привлечением операторов связи частных коммерческих компаний, а это значит, что их основной целью явмяется получение прибыли. Очевидно, что установка оборудования в отдаленных малонаселенных пунктах Аля них чаще всего не имеет коммерческого интереса.

В связи с этим возникает пробцема соџиального неравенства граждан Российской Федерации. Необходимо признать, что полного равенства в этом вопросе в нынешних условиях достичь практически невозможно. ОАнако, как замечает А.С. Кусков, если мы живем в одной стране, то у нас Аолжны быть хотя бы примерно одинаковые возможности [13] . В эпоху масштабного развития цифровых технологий неАопустимо, чтобы отдельные члены общества не имели возможности пользоваться сотовой связью и получать государственные услуги, не говоря уже о более сложных технологиях. 
Есть опасения, что глобальная цифровизация общества вместе со всеми преимуществами дмя коренных народов может оказать и негативное воздействие на их национально-культурную идентичность. Новые возможности цифровых технологий способствуют отказу от сформировавшегося за многие года традиционного образа сушествования, в котором определенные элементы обыденной жизни преАставляют огромную историческую ценность. Именно поэтому процесс цифровизации в таких случаях должен внеАряться максимально корректно, чтобы не нанести необратимого ущерба. Е.А. Аеонтенкова справедливо отмечает, что при внедрении цифровых технологий в национально-культурное пространство возникает потребность юридического оформления и фиксации особых мер, направленных на сохранение этнокультурной идентичности традиционных сообществ в условиях цифровых, информационных сАвигов в развитии человеческой культуры и цивилизации $[15$, c. 172$]$.

Основной Закон России в ч. 2 ст. 69 защищает нащионально-культурную идентичность и самобытность всех коренных малочисленных народов Российской Федерации и гарантирует им сохранение этнокультурного и языкового многообразия [3]. Аанная норма Конституции РФ была принята в ходе общероссийского голосования по вопросу одобрения изменений в Конституџию РФ, которое проводилось с 25 июня по 1 июля 2020 г. Это свидетельствует о понимании органами государственной вмасти всей остроты проблемы и необходимости проведения незамедлительной работы в этом направлении. Реализаџия Аанной конституционной нормы требует принятия законодательных и иных мер по конкретизации механизма наџионально-культурной идентичности и самобытности соџиальных общностей. «... Цифровизащия как объективный, неизбежный процесс трансформирует содержание конституционных норм и принципов, конституционных ценностей», а в конченом итоге определяет вектор развития не только конституционного, но и информационного законодательства [16, с. 20].

Н.Ю. Буряк пишет, что в условиях глобального процесса цифровизации не очень комфортно себя чувствуют языки коренных народов [17, с. 62], которые становятся жертвами более крупных языков. В силу того, что в Российской Федерации государственным языком является русский и образование можно получить, за редким исключением, только на русском языке, в сфере государственного документооборота используется русский язык, мюбые электронные ресурсы функционируют на русском языке и т.А., многие преАставители малых народов считают свой язык непопулярным, а порой и вовсе не нужным в современном обществе.

Это и есть противоположная сторона внедрения новых цифровых 
технологий, которая оказывает негативное воздействие на национальнокультурную идентичность коренных народов. ОАной из причин такого рода явлений является возможность тесного общения через электронные ресурсы всех мюдей межАу собой. Как описывает данную ситуацию А.А. Зорин, каждый человек теперь находится от Аругого человека на расстоянии четырех нажатий кнопок на своем смартфоне [18, с. 5] .

На наш взгляА, самой большой причиной исчезновения языков мамых народов явмяется уменьшение количества носителей этого языка. Һюди часто считают его изучение не нужным, так как это не отвечает нынешним требованиям. При спасении языкового наследия народов России цифровые технологии могли бы оказать необходимую помощь. Программа по сохранению языкового и культурного наследия народов Арктики явмяется примером в этом направлении.

Ю.И. Скуратов утверждает, что более широкое закрепление в Конституции РФ прав народа, в том числе и его суверенных прав в различных

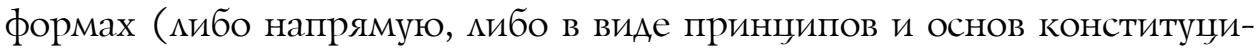
онного строя), позволит обеспечить взаимодействие коммективных и индивидуальных прав. Иными словами, социальные возможности нароАа, его права, выраженные непосредственно или как принџипы конституџионного строя, Аолжны преломиться, найти свое отражение в правах человека и гражданина. И наоборот, права человека и гражданина, имеющие всеобщий и общезначимый, а не мичный характер, необходимо формулировать как принцип конституџионного строя [19, с. 15].

В периол цифровизации обобщение и анализ всех имеющихся цифровых ресурсов, где сосредоточено огромное количество информационной базы, невозможкно без всестороннего взаимодействия общества и государства. Это позволит использовать более качественные методы, основанные на систематизации информационно-правовой среды. Считаем необходимым дальнейшее развитие цифровых технологий в среде обитания коренных малочисленных народов, чтобы устранить существуюшую разницу в возможностях современного цифрового мира в российском обществе.

\section{Библиографический список}

1. Велиева Д.С. Коллективные субъекты конституционных прав // Вестник Саратовской государственной юридической академии. 2013. № 4(93). С. 205-208.

2. Зборовский Г.Е. Теоретические основания изучения социальной общности // Социологические исследования. 2010. № 4(312). С. 3-12.

3. Конституция Российской Федерации: принята всенародным голосованием 12 дек. 1993 г. с изменениями, одобренными в ходе общероссийского голосования 1 июля 2020 г. // СЗ РФ. 2020. № 11. Ст. 1416.

4. Брянцев И.И., Брянцева О.В. Правовое регулирование общественных отношений в условиях цифровизации: институты и институциональная среда // Вестник По- 
волжского института управления. 2021. № 21(2). С. 56-64.

5. Проект «Цифровизация языкового и культурного наследия коренных народов Арктики» / Рабочая группа по устойчивому развитию в Арктике // The Northern Forum. URL: https://www.northernforum.org/ru/news-ru/856-proekt-tsifrovizatsiya-yazykovogo-i-kulturnogo-naslediya-korennykh-narodov-arktiki-byl-predstavlen-na-soveshchanii-rabochej-gruppy-po-ustojchivomu-razvitiyu-v-arktike

6. Медицина через расстояние // RG.RU. URL: https:/www.google.com/amp/s/rg.ru/ amp/2019/10/20/cifrovizaciia-obespechivaet-dostupnuiu-medpomoshch-v-udalennyhrajonah.html

7. Об основах охраны здоровья граждан Российской Федерации: Федер. закон от 21 нояб. 2011 г. № 323-Ф3 (с изм. от 2 июля 2021 г. № 358-ФЗ) // СЗ РФ. № 48. Ст. 6724.

8. Габазова Я.Д. Международная оценка развития электронного правительства в Российской Федерации (на примере индекса развития электронного правительства ООН) // Молодой исследователь Дона. 2017. № 5(8). С. 170-177.

9. О государственной программе «Информационное общество (2011-2020 годы)» / Правительство Российской Федерации: официальный сайт. URL: http:/government.ru/ $\operatorname{docs} / 3369 /$

10. Дацєков C.В. Организационное обеспечение подготовки специалистов по заочной форме с использованием дистанционных образовательных технологий // Вестник Казанского технологического университета. 2009. № 2. С. 54-56.

11. Методические рекомендации по реализации образовательных программ начального общего, основного общего, среднего общего образования, образовательных программ среднего профессионального образования и дополнительных общеобразовательных программ с применением электронного обучения и дистанционных образовательных технологий / Министерство просвещения РФ: официальный сайт. URL: https://docs.edu.gov.ru/document/26aa857e0152bd199507ffaa15f77c58/

12. Программа по устранению цифрового неравенства // TADVISER. URL: https:// www.tadviser.ru/index.php/

13. Объять необъятное: 25 тыс. населенных пунктов России живут без интернета и телефонии // COMNEWS. URL: https://www.comnews.ru/content/208395/2020-0731/2020-w31/obyat-neobyatnoe-25-tys-naselennykh-punktov-rossii-zhivut-bez-internetai-telefonii

14. О связи: Федер. закон от 7 июля 2003 г. №-126-Ф3 (с изм. от 2 июля 2021 г. № 331Ф3) // С3 РФ. 2003. № 28. Ст. 2895.

15. Леонтенкова E. А. Право и этнокультурная идентичность в условиях цифровизации // Вестник Нижегородской академии МВД России. 2021. № 2(54). С. 170-176.

16. Велиева Д.С. Цифровые права в системе конституционных прав и свобод с позиции правовой определенности // Трансформация и цифровизация правового регулирования общественных отношений в современных реалиях и условиях пандемии / под ред. И.В. Воронцовой. Казань, 2020.

17. Буряк Н.Ю. Проблемы исчезновения языков малых народов в России // Тенденции развития науки и образования. 2019. № 50-10. С. 60-62.

18. Зорин А.Л. Цифровизация и общество // Культура и время перемен. 2021. № 1(32). С. 1-16.

19. Скуратов Ю.И. Категория «народ» в конституционном праве России (евра- 